\title{
Survival and growth of Pseudoplatystoma corruscans (Pisces - Pimelodidae) larvae: effect of photoperiod
}

[Sobrevivência e crescimento de larvas de surubim, Pseudoplatystoma corruscans (Pisces, Pimelodidae): efeito do fotoperiodo]

R. Campagnolo ${ }^{1}$, A.P.O. Nuñer ${ }^{2 *}$

${ }^{1}$ Aluno de pós-graduação - UFSC - Florianópolis, SC

${ }^{2}$ Departamento de Aqüicultura - CCA-UFSC

Rodovia SC 406, 3532

88066-000 - Florianópolis, SC

\begin{abstract}
The survival and the growth of Pseudoplatystoma corruscans larvae exposed to four photoperiods: light:dark (LD) 0:24, LD 10:14, LD 14:10, and LD 24:0, in a brackish water (5\%) culture were analyzed. Larvae were fed with Artemia sp. nauplii at a 500 nauplii/larvae/day ratio. Survival on day 5 was inversely related to the length of photoperiod. From days 5 to 10, intermediate photoperiods resulted in a better survival, although LD 0:24 and LD 14:10 resulted in similar survival on day 10. Larvae presented higher weight at intermediate photoperiods. The results suggested that photoperiod requirements shifted during early development of $P$. corruscans larvae.
\end{abstract}

Keywords: surubim, Pseudoplatystoma corruscans, larvae, photoperiod, survival, growth

\section{RESUMO}

A sobrevivência e o crescimento de larvas de surubim, Pseudoplatystoma corruscans, submetidas a quatro fotoperiodos: luz:escuro (LE) 0:24, LE 10:14, LE 14:10 e LE 24:0 em água salinizada (5\%o) foram avaliadas. As larvas foram alimentadas com náuplios de Artemia sp. na proporção de 500 náuplios/larva/dia. Após cinco dias de experimento, a sobrevivência apresentou relação inversa ao aumento do fotoperiodo. Entre o quinto e o $10^{-}$dia, houve tendência de maior sobrevivência nos fotoperiodos intermediários, mas foram registradas sobrevivências semelhantes no intervalo entre LE 0:24 e LE 14:10 no 10 dia. As larvas apresentaram maior peso nos fotoperiodos intermediários. Os resultados sugerem que a exigência de fotoperiodo das larvas de $\mathrm{P}$. corruscans sofre mudanças durante o cultivo.

Palavras-chave: surubim, Pseudoplatystoma corruscans, larva, fotoperiodo, sobrevivência, crescimento

\section{INTRODUCTION}

Fundamental biological rhythms in nature are frequently related to the periodicity of light and many animals, including fish, exhibit a 24-hour cycle in their activities (Boeuf and Le Bail, 1999). This cycle dictates the feeding rhythm and is specific for each species, being classified as diurnal, nocturnal, or diurnal-nocturnal (ZavalaCamin, 1996).

The mechanism which regulates that rhythm and produces effects on growth are not completely clear, but photoperiod can influence the release of several hormones that affect fish larvae development and performance (Hart et al., 1996; Boeuf and Le Bail, 1999). However, the best photoperiod for growth is frequently not the best one for survival (Boeuf and Le Bail, 1999; Fielder et al., 2002).

Photoperiod requirements are specific for each species, and the positive effects on the growth and/or survival can occur under continuous light (Reynalte-Tataje et al., 2002; Moustakas et al.,

Recebido em 4 de março de 2008

Aceito em 23 de outubro de 2008

*Autor para correspondência (corresponding author)

E-mail: apon@cca.ufsc.br 
2004), intermediary photoperiods (Cerqueira and Chatain, 2001; Solbakken and Pittman, 2004), or continuous darkness (Piaia et al., 1999; Baldisserotto, 2002). The light:dark (LD) photoperiod 0:24 has been associated with better development of Siluriformes fish with some exceptions (Nwosu and Holzlöhner, 2000; Giri et al., 2002). Photoperiod requirements also vary according to the ontogenetic developmental stage (Puvanendran and Brown, 2002; Kestemont et al., 2003).

The surubim Pseudoplatystoma corruscans (Spix \& Agassiz, 1829) is one of the most important Brazilian native species used in fish culture (Cury, 1992; Ribeiro and Miranda, 1997; Inoue et al., 2003). However, studies related to the initial stages of development of this species are still scarce.

Currently surubim is usually grown under darkness thus demonstrating the influence of photoperiod on this species. The present study was carried out to evaluate the survival and growth of surubim larvae exposed to different photoperiods.

\section{MATERIAL AND METHODS}

The study was carried out at São Carlos Fish Culture Station in Santa Catarina State, Brazil. Larvae were obtained from induced spawning using the protocol described by Zaniboni-Filho and Barbosa (1996).

The eggs were incubated in 2001 funnel incubators with constant water flow and natural photoperiod. After hatching, the larvae were continuously observed to identify the moment of mouth opening. At that time, the mean ( \pm standard deviation) total length was $4.45 \pm 0.03 \mathrm{~mm}$ and mean weight was $0.57 \pm 0.04 \mathrm{mg}$. Larvae were transferred to white, circular plastic fishbowls containing 51 of aerated $5 \%$ brackish water. These experimental units consisted of a closed system without water recirculation and the stocking density was 15 larvae/l.

During the experimental period the water temperature and the dissolved oxygen concentration (DOC) were monitored twice daily, in the morning and in the afternoon, with a YSI-55 oxygen meter. The $\mathrm{pH}$, total ammonia, and nitrite concentrations were recorded each afternoon, with a YSI-60 pHmeter and colorimetric methods, respectively.

Four photoperiods were randomly applied as treatments in triplicate: LD 0:24, LD 10:14, LD
14:10, and LD 24:0. However, one experimental unit in LD 0:24 treatment was lost during the experiment due to an incorrect management and was not included in the analysis.

The larvae were fed with Artemia nauplii at a rate of 500 nauplii/larvae/day using a four-hour interval that started daily at $08: 00 \mathrm{~h}$. The experimental units were siphoned daily with $0.2 \mathrm{~mm}$ screened hose until $40 \%$ of water was removed. That volume was immediately replaced after the cleaning procedure.

On day 5 of cultivation, survival was evaluated by counting all surviving larvae. The study was ended on day 10 , when all larvae of each experimental unit were sieved and preserved in a $4 \%$ formaldehyde solution for further measurements of length, weight, and survival.

The survival was calculated for days 5 and 10 and for the period between them using the initial number of fish stocked as reference: $\mathrm{S}=$ (N10/N5)100, being: S was the survival (\%) from days 5 and 10, N10 the number of survivors on day 10 , and N5 the number of survivors on day 5 .

Simple regression analysis (Zar, 1996) was used to establish the relationship of survival, weight, and length with the photoperiod. Each regression was found and tested $(\alpha=0.05)$ with GraphPad Prism 4.0 software and only valid regressions were presented.

\section{RESULTS}

Water temperature, $\mathrm{pH}, \mathrm{DOC}$, total ammonia, and nitrite concentrations were similar among treatments and stayed within the acceptable range for fish cultivation (Boyd, 1990), with means ( \pm standard deviation) of $25.4 \pm 0.09$ and $26.0 \pm 0.05^{\circ} \mathrm{C}$ for morning and afternoon temperatures, respectively; $7.5 \pm 0.01$ for $\mathrm{pH}, 7.7 \pm 0.01$ and $7.4 \pm 0.02 \mathrm{mg} / 1$ for morning and afternoon DOC, respectively; $0.31 \pm 0.01 \mathrm{mg} / 1$ for total ammonia; and $0.22 \pm 0.02 \mathrm{mg} / 1$ for nitrite.

On day 5 and 10 (Fig. $1 \mathrm{a}$ and b), the survival presented relationship inversely proportional $(\mathrm{P}<0.05)$ to photoperiod increase, but on day 10 , the decrease was less accentuated. From days 5 to 10 , the survival showed stabilization $(\mathrm{P}<0.05)$ in the intermediary photoperiods (LD 10:14 and LD 14:10) and reduction in the extreme photoperiods (Fig. 2).

The growth in weight was better $(\mathrm{P}<0.05)$ in intermediary photoperiods (Fig. 3a), but that relationship was not observed $(\mathrm{P}>0.05)$ for total length (Fig. 3b). 


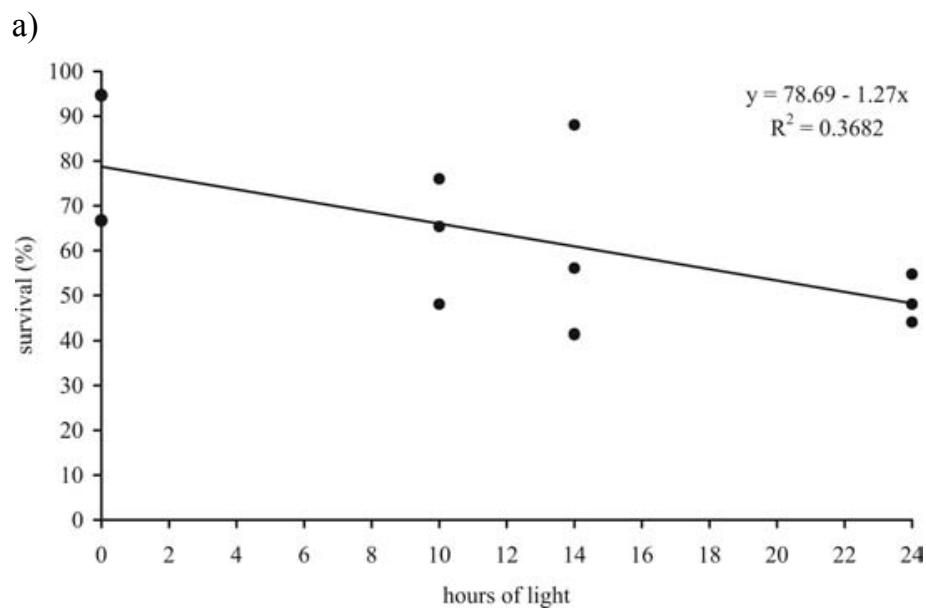

b)

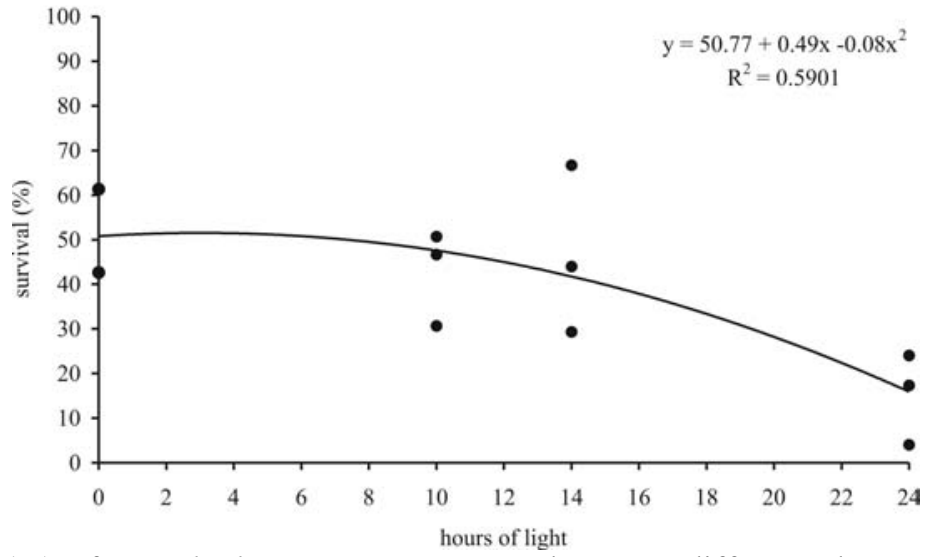

Figure 1. Survival (\%) of Pseudoplatystoma corruscans larvae at different photoperiods. a) After five days of cultivation. b) After ten days of cultivation. Slope significant at $5 \%$ of significance level.

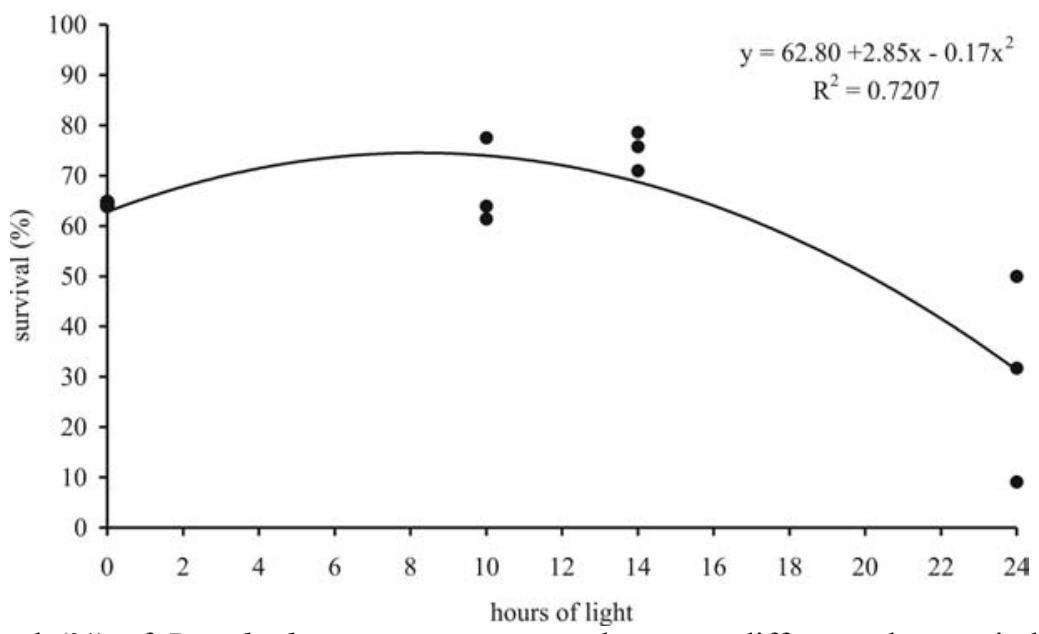

Figure 2. Survival (\%) of Pseudoplatystoma corruscans larvae at different photoperiods between days five and ten of cultivation. Slope significant at $5 \%$ of significance level. 
a)

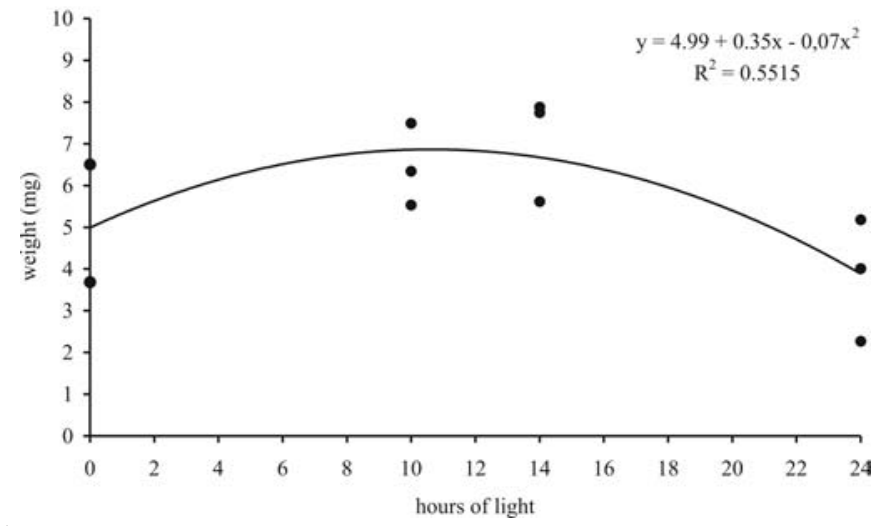

b)

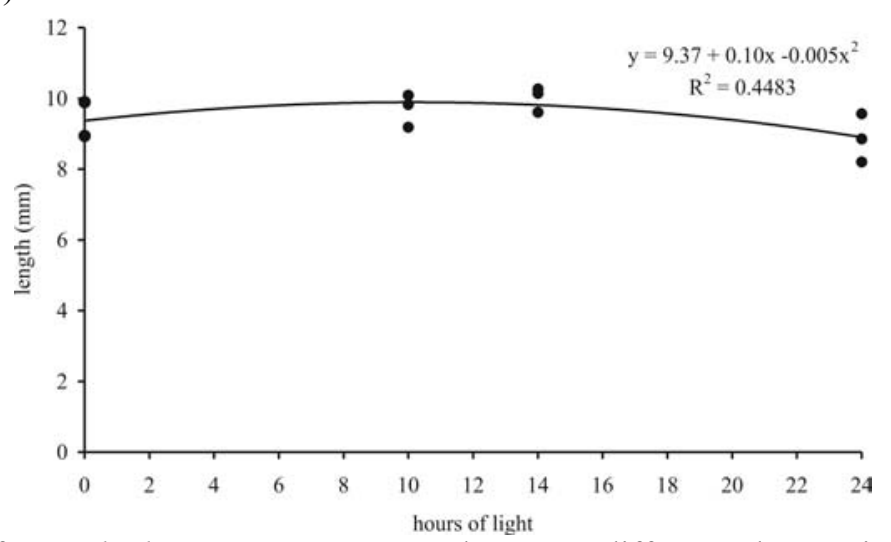

Figure 3. Growth of Pseudoplatystoma corruscans larvae at different photoperiods after ten days of cultivation. a) Total weight (mg); b) Total length (mm). Slope significant at 5\% of significance level.

\section{DISCUSSION}

The smallest survival rates registered at LD 24:0 on days 5 and 10 day may be associated with the intense larvae swimming activity, higher energy consumption and, as consequence, reduction of survival, a condition registered at the initial feeding phase for Clarias gariepinus (Appelbaum and Mcgeer, 1998), Dicentrarchus labrax (Cerqueira and Chatain, 2001), Paralichthys lethostigma (Tuckey and Smith, 2001), and for Clarias gariepinus juveniles (Almazán-Rueda et al., 2004).

The increase in swimming activity in the tallest fish is associated with a decrease in the concentration of melatonin (Ekström and Meissl, 1997), a hormone synthesized by the pineal organ that reaches basal levels in plasma in the presence of light; whereas in the dark, the levels rise and reach a maximum value. This light-dark changing in melatonin concentration is a condition that occurs in natural photoperiods and that is called stable rhythm. The pineal organ is involved in the releasing of hormones that affect the growth and the survival of fish (Boeuf and Le Bail, 1999).

In periods of continuous darkness, melatonin presents a stable rhythm for some time, but after few days, it decreases in most teleost due to an internal mechanism of control located in the pineal. That mechanism, however, is not triggered in the presence of continuous light.

The maintenance of a stable rhythm of melatonin production during the first days followed by reduction, as registered to Ictalurus punctatus, which showed a stable rhythm of melatonin production during four days in a condition of complete darkness (Bolliet et al., 1996), can explain the higher survival registered on day 5 at LD 0:24 compared to that obtained on day 10 for the same photoperiod. 
The higher survival rates registered in intermediary photoperiods showed that surubim larvae benefited from the daily dark:light cycle, a condition that maintains the stable rhythm of melatonin production. Intermediary photoperiods were also better for larvae survival of other species at the beginning of the feeding (Barahona-Fernandes, 1979; Martin-Robichaud and Peterson, 1998).

Survival rates registered at the end of the experiment (day 10) in LD 0:24, LD 10:14, and LD 14:10 were higher than those registered on the 5 th day (9.63\%) for Lopes et al. (1996).

Similarly to survival, the surubim larvae growth in weight was negatively influenced by energy consumption increase in LD 24:0, which was also registered for Pagrus auratus larvae during the air-filling phase of gaseous vesicle (Fielder et al., 2002). On the other hand, the absence of light in LD 0:24 did not allow growth to reach its maximum, since accordingly to Boeuf and Le Bail (1999), there is a synergic effect between light and food availability that can favor the larvae growth probably due to the releasing of hormones such as somatotropin. Even if food was available or detected with the aid of the barbells (Nwosu and Holzlöhner, 2000), this synergism could not occur under continuous darkness because light was absent.

The better growth registered in intermediary photoperiods was not registered for other Siluriformes like Clarias gariepinus larvae during the initial phase of feeding (Appelbaum and McGeer, 1988) and Rhamdia quelen larvae and juveniles (Behr et al., 1999; Piaia et al., 1999) whose better growth were registered in LD $0: 24$. Similar results were registered in the initial cultivation of Heterobranchus longifilis larvae (Nwosu and Holzlöhner, 2000) and Wallago attu (Giri et al., 2002).

Therefore, the decrease in survival on day 10 compared to high survival on day 5 in $\operatorname{LD}$ 0:24 indicated a shift in the response of surubim larvae to photoperiod. During the first five days, the absence of light was a favorable condition, but on day 10 it was not. The better growth in weight on day 10 was registered in intermediate photoperiods, confirming that presence of light became an important factor to larvae development.

\section{CONCLUSIONS}

Continuous absence of light was an important condition during the first five days of surubim larvae cultivation, but after that period complete darkness was not a favorable condition. Intermediary photoperiods provided better growth in weight at the end of the experiment, suggesting that larvae photoperiod requirements shifted from continuous darkness at the beginning of the development to a condition with intermediate light availability.

\section{ACKNOWLEDGEMENTS}

The authors thank Tractebel Energia for the financial support and CAPES for the scholarship granted to the first author.

\section{REFERENCES}

ALMAZÁN-RUEDA, P.; SCHRAMA, J.W.; VERRETH, J.A.J. Behavioural responses under different feeding methods and light regimes of the African catfish (Clarias gariepinus) juveniles. Aquaculture, v.231, p.347-359, 2004.

APPELBAUM, S.; McGEER, J.C. Effect of diet and light regime on growth and survival of African catfish (Clarias gariepinus) larvae and early juvenile. Aquac. Nutr., v.4, p.157-164, 1998.

BALDISSEROTTO, B. Fisiologia de peixes aplicada à piscicultura. Santa Maria: Editora UFSM, 2002.

BARAHONA-FERNANDES, M.H. Some effects of light intensity and photoperiod on the sea bass larvae (Dicentrarchus labrax L.) reared at the Centre Océanologique de Bretagne. Aquaculture, v.17, p.311$321,1979$.

BEHR, E.R.; RANDÜNZ NETO, J.; TRONCO, A.P. et al. Influência de diferentes níveis de luminosidade sobre o desempenho de larvas de jundiá (Rhamdia quelen) (Quoy e Gaimard, 1824) (Pisces: Pimelodidae). Acta Scient., v.21, p.325-330, 1999.

BOEUF, G.; LE BAIL, P.Y. Does light have an influence on fish growth? Aquaculture, v.177, p.129$152,1999$.

BOLLIET, V.; ALI, M.A.; LAPOINTE, F.J. et al. Rhythmic melatonin secretion in different teleost species: an in vitro study. J. Comp. Physiol. Part B, v.165, p.677-683, 1996.

BOYD, C.E. Water quality in ponds for aquaculture. Alabama: Birmingham Publishing, 1990.

CERQUEIRA, R.V.; CHATAIN, B. Photoperiodic effects on the growth and feeding rhythm of European 
sea bass, Dicentrarchus labrax, larvae in intensive rearing. EAS Spec. Publ., v.30, p.304-306, 2001.

CURY, M.X. Cultivo de pintado e cachara. Rev. Pan. Aquic., v.2, p.8-9, 1992.

EKSTRÖM, P.; MEISSL, H. The pineal organ of teleost fishes. Rev. Fish Biol. Fish., v.7, p.199-284, 1997.

FIELDER, D.S.; BARDSLEY, W.J.; ALLAN, G.L. et al. Effect of photoperiod on growth and survival of snapper Pagrus auratus larvae. Aquaculture, v.211, p.135-150, 2002.

GIRI, S.S.; SAHOO, S.K.; SAHU, B.B. et al. Larval survival and growth in Wallago attu (Bloch and Schneider): effects of light, photoperiod and feeding regimes. Aquaculture, v.213, p.151-161, 2002.

HART, P.R.; HUTCHINSON, W.G.; PURSER, G.J. Effects of photoperiod, temperature and salinity on hatchery-reared larvae of the greenback flounder (Rhombosolea tapirina Günther, 1862). Aquaculture, v.144, p.303-311, 1996.

INOUE, L.A.K.A.; CECCARELLI, P.S. SENHORINI, J.A. A larvicultura e a alevinagem do pintado e do cachara. Rev. Pan. Aquic., v.13, p.15-21, 2003

KESTEMONT, P.; JOURDAN, S.; HOUBART, M. et al. Size heterogeneity, cannibalism and competition in culture predatory fish larvae: biotic and abiotic influences. Aquaculture, v.227, p.333-356, 2003.

LOPES, M.C.; FREIRE, R.A.B.; VICENSOTTO, J.R.M. et al. Alimentação de larvas de surubim pintado, Pseudoplatystoma corruscans (Spix \& Agassiz, 1829) em laboratório, na primeira semana de vida. Bol. Tec. CEPTA, v.9, p.11-29, 1996.

MARTIN-ROBICHAUD, D.J.; PETERSON, R.H Effects of light intensity, tank colour and photoperiod on swimbladder inflation success in larval striped bass, Morone saxatilis (Walbaum). Aquac. Res., v.29, p.539-547, 1998

MOUSTAKAS, C.T.H.; WATANABE, W.O; COPELAND, K.A. Combined effects of photoperiod and salinity on growth, survival, and osmoregulatory ability of larval southern flounder Paralichthys lethostigma. Aquaculture, v.229, p.159-179, 2004.

NWOSU, F.M.; HOLZLÖHNER, S. Effect of light periodicity and intensity on the growth and survival of Heterobranchus longifilis Val. 1840 (Teleostei: Clariidae) larvae after 14 days of rearing. J. Appl. Ichthyol., v.16, p.24-26, 2000.

PIAIA, R.; TOWNSEND, C.R.; BALDISSEROTTO, B. Growth and survival of fingerlings of silver catfish exposed to different photoperiods. Aquac. Int., v.7, p.201-205, 1999.

PUVANENDRAN, V.; BROWN, J.A. Foraging, growth and survival of Atlantic cod larvae reared in different light intensities and photoperiods. Aquaculture, v.214, p.131-151, 2002.

REYNALTE-TATAJE, D.; LUZ, R.K.; MEURER, S. et al. Influência do fotoperíodo no crescimento e sobrevivência de pós-larvas de piracanjuba Brycon orbignyanus (Valenciennes, 1849) (Osteichthyes, Characidae). Acta Sci., v.24, p.439-443, 2002.

RIBEIRO, L.P.; MIRANDA, M.O.T. Rendimentos de processamento do surubim Pseudoplatystoma corruscans. In: MIRANDA, M.O.T. (Ed). Surubim. Belo Horizonte: IBAMA, 1997. p.101-111.

SOLBAKKEN, J.S.; PITTMAN, K. Photoperiodic modulation of metamorphosis in Atlantic halibut (Hippoglossus hippoglossus L.). Aquaculture, v.232, p.613-625, 2004.

TUCKEY, L.M.; SMITH, T.I.J. Effects of photoperiod and substrate on larval development and substrate preference of juvenile Southern flounder, Paralichthys lethostigma. J. Appl. Aquac., v.11, p.1-20, 2001.

ZANIBONI FILHO, E.; BARBOSA, N.D.C. Priming hormone administration to induce spawning of some Brazilian migratory fish. Rev. Bras. Biol., v.56, p.655659, 1996.

ZAR, J.H. Biostatistical analysis. 3.ed. New Jersey: Prentice Hall, 1996

ZAVALA-CAMIN, L.A. Introdução aos estudos sobre alimentação natural em peixes. Maringá: EDUEM, 1996. 